\section{BM Paediatrics Open}

\title{
Demographic characteristics of labial adhesion in South Korea: a population- based study from 2010 to 2014
}

\author{
In Ok Lee, ${ }^{1}$ Hae Yong Pak, ${ }^{2}$ Jae Eun Chung ${ }^{1}$
}

To cite: Lee IO, Pak HY, Chung JE. Demographic characteristics of labial adhesion in South Korea: a population-based study from 2010 to 2014. BMJ Paediatrics Open 2018;2:e000276. doi:10.1136/ bmjpo-2018-000276

Received 23 February 2018 Revised 23 May 2018 Accepted 25 May 2018
Check for updates

${ }^{1}$ Department of Obstetrics and Gynecology, National Health Insurance Service llsan Hospital, Goyang, South Korea ${ }^{2}$ Institute of Health Insurance and Clinical Research, National Health Insurance Service Ilsan Hospital, Goyang, South Korea

Correspondence to Dr Jae Eun Chung; jiupark@ naver.com

\section{ABSTRACT \\ Objective To investigate the demographic features of labial adhesion (LA) in South Korea. \\ Design A population-based nationwide study. \\ Setting Census population of South Korea. \\ Participants With the entire population of South Korea ( $\mathrm{n}=47990761$ ), patients under age 7 who were newly diagnosed with LA from January 2010 to December 2014 were included.}

Main outcome measure The average incidence and the peak age of LA occurrence were estimated.

Results A total of 4934 newly diagnosed LAs were analysed. The incidence of $L A$ has constantly increased since 2008, the year that the Korean Developmental Screening Test for InfantsandChildren registry began. The average incidence of LA was 55.0 cases/100 000 personyears $(95 \% \mathrm{Cl} 53.5$ to 56.6$)$. The highest incidence was 183.6 cases/100 000 person-years $(95 \% \mathrm{Cl} 175.8$ to 191.6$)$ in the age group of 13 to 24 months. The relative risk of acquiring LA in the age group of 13 to 24 months was 1.481 (95\% Cl 1.381 to 1.587$)$ compared with the age group of 0 to 12 months.

Conclusions The demographic characteristics of LA including the average incidence and the highest incidence age group in South Korea were revealed in this nationwide, population-based study including a total of 4934 newly developed LA cases. Further studies are needed to reveal the natural disease course and the significance of diagnosing asymptomatic LA cases.

\section{INTRODUCTION}

Labial adhesion (LA), also called labial agglutination or labial fusion, is the partial or complete adherence of labia minora in the midline. ${ }^{1}$ It is known to be an acquired condition without any accompanying congenital malformation in the upper genital tract. ${ }^{2} \mathrm{LA}$ is thought to be caused by the low-oestrogen environment, which easily results in vulvar inflammation and concomitant labial re-epithelialisation. ${ }^{3}$ Numerous treatment options have been suggested with varying success rates. ${ }^{4}$

Korean National Health Insurance Service (KNHIS) covers more than $90 \%$ of the whole population in South Korea since 1989, and all healthcare-related data including the disease

\section{What is already known on this topic?}

- The cause of labial adhesion (LA) is unclear, but it is thought to be not related to a congenital pathology.

- Most patients with LA are asymptomatic and the adhesions may resolve on their own, rendering the treatment options variable.

- Urinary infection, vaginal irritation and dripping of urine are some of the possible accompanied symptoms.

\section{What this study hopes to add?}

In this population-based study, analysing a total of 4934 LA cases, the average incidence of LA was 550 cases $/ 100000$ person-years $(95 \% \mathrm{Cl} 53.5$ to 56.6).

- The highest incidence was 183.6 cases/100 000 person-years $(95 \% \mathrm{Cl} 175.8$ to 191.6$)$ in the age group of 13 to 24 months.

- Further studies are needed to reveal the natural disease course and the significance of diagnosing asymptomatic LA cases.

code, date of birth, history of hospital admission and prescriptions given are collected in the Korea National Insurance Claims Database (KNICD), which began in 2005. According to the International Classification of Diseases (ICD-10), Q525 is the single code assigned to LA.

From 2008, Korean Developmental Screening Test for Infants and Children (KDST) has been initiated. Rather than visiting the paediatrician after having clinical symptoms, this voluntary health check-up supports the proper growth and development. When LA is noted, the patient is referred to a paediatric gynaecologist under the discretion of the primary physician. The consulting gynaecologist examines the patient again and, if appropriate, registers the patient with the Q525 code and treats her accordingly.

Several studies have reported the incidence of LA based on a very limited number of 
patients with varying results. ${ }^{5-7}$ This nationwide, population-based study with 4934 LA cases should provide an evidence based data of an accurate incidence and demographic feature of LA in South Korea.

\section{MATERIALS AND METHODS}

\section{LA diagnosis in South Korea and its definition}

LA is represented by diagnostic code Q525, based on the ICD-10 code system in the KNICD. From 2005 to 2014, all the cases with Q525 were obtained. As there were no newly diagnosed cases reported after the age of 7 , children under age 7 were only included. The incidence of LA was calculated as the number of newly reported LA over the number of the female population of that particular age group in the particular year. The midyear population from which the census information is gathered on 1 July of each year in the resident registration of the South Korea census bureau was used. The Poisson distribution was used to estimate 95\% CIs for average incidence of LA. Peak age of LA occurrence was calculated. The relative risk (RR) and 95\% CI for each age group were calculated. All the values were estimated with the age group of $0-12$ months as the reference.

All statistical analyses were performed using SAS V.9.4. P values less than 0.05 were considered statistically significant.

\section{RESULTS}

The number of newly diagnosed LA has increased from 101 cases in 2005 when the KNICD took hold to 1489 cases in 2014. The abrupt increment of the reported LA cases since the initiation of KDST in 2008 was notable (figure 1).

From 2010 to 2014, a total of 4934 newly developed LA cases were noted, and the average incidence of LA was 55.0 cases/100 000 person-years. The annual incidence showed a constant increase from 36.1 cases/100 000 person-years in 2010 to 82.7 cases/ 100000 person-years in 2014 (table 1).

Sorted by age group, the group of 13 to 24 months showed the highest average incidence of 183.6 cases / 100000 person-years (95\% CI 175.8 to 191.6). The group of 0 to 12 months followed with the average incidence of 124.0 cases $/ 100000$ person-years (95\% CI 117.4 to 130.8) (table 2, figure 2).

The relative risk of acquiring LA in the age group of 13 to 24 months was 1.481 (95\% CI 1.381 to 1.587 ) compared with the reference age group of 0 to 12 months. The relative risk of acquiring LA in the age group of 25 to 36 months was 0.535 (95\% CI 0.488 to 0.585 ), and it showed a decreasing pattern as the patient got older (table 3 ).

\section{DISCUSSION}

A total number of 4934 newly developed LA cases from 2010 to 2014 were analysed. This nationwide, population-based study was based on the KNHIS and KNICD that encompasses more than $90 \%$ of the total South Korean population and includes data such as the disease code, date of birth, history of hospital admission and prescriptions given. For a rare disease such as LA, a population-based study might be considered as an ideal setting to calculate the incidence and demographic characteristics. The average incidence of LA was 55.0 cases / 100000 person-years (table 1).

With the initiation of KDST in 2008, rather than visiting the paediatrician after the development of clinical symptoms, children could get a free yearly health check-up to ensure the proper growth and development. Reported cases of LA have abruptly increased from 101 cases in 2005 when the KNICD started gathering healthcare-related data to 1489 cases in 2014. This increase in LA cases with the initiation of the KDST registry can be

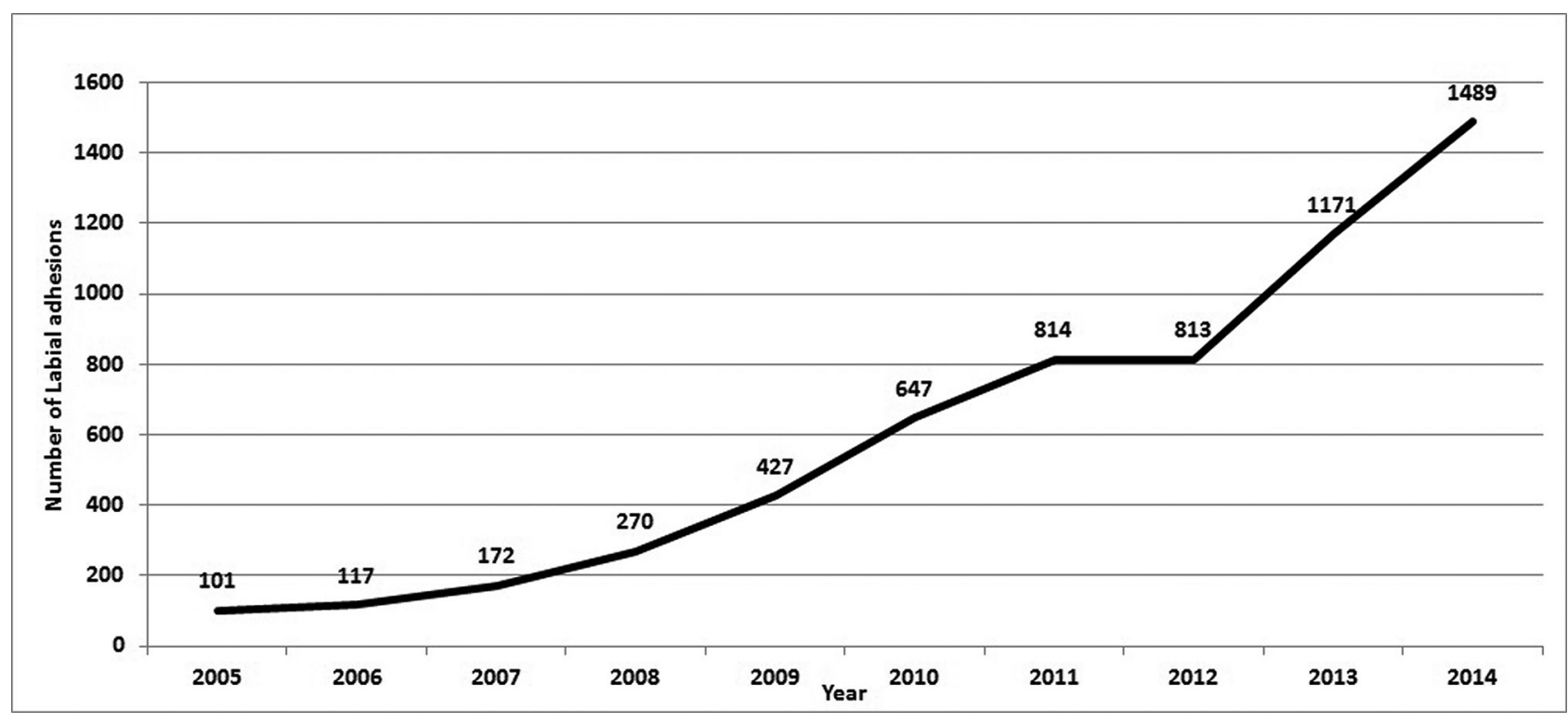

Figure 1 Number of newly diagnosed labial adhesions from 2005 to 2014. 
Table 1 Annual incidence of labial adhesions per 100000 person-years classified by age group from 2010 to 2014

\begin{tabular}{|c|c|c|c|c|c|c|c|}
\hline $\begin{array}{l}\text { Age } \\
\text { (months) }\end{array}$ & 2010 & 2011 & 2012 & 2013 & 2014 & Total & $P$ values \\
\hline $0-12$ & $\begin{array}{l}56.8 \\
\text { (47.1 to } 67.9)\end{array}$ & $\begin{array}{l}84.7 \\
\text { (73.0 to } 97.9)\end{array}$ & $\begin{array}{l}98.4 \\
\text { (85.8 to } 112.3)\end{array}$ & $\begin{array}{l}165.2 \\
\text { (148.5 to } 183.3 \text { ) }\end{array}$ & $\begin{array}{l}219.6 \\
\text { (199.8 to } 240.8 \text { ) }\end{array}$ & 124.0 & $<0.0001$ \\
\hline $13-24$ & $\begin{array}{l}111.3 \\
\text { (97.8 to } 126.1 \text { ) }\end{array}$ & $\begin{array}{l}157.2 \\
(141.1 \text { to } 174.6)\end{array}$ & $\begin{array}{l}142.1 \\
(127.1 \text { to } 158.4)\end{array}$ & $\begin{array}{l}215.2 \\
(196.8 \text { to } 234.9)\end{array}$ & $\begin{array}{l}289.5 \\
(267.7 \text { to } 312.5)\end{array}$ & 183.6 & $<0.0001$ \\
\hline $25-36$ & $\begin{array}{l}53.3 \\
(44.4 \text { to } 63.6)\end{array}$ & $\begin{array}{l}56.6 \\
(47.1 \text { to } 67.4)\end{array}$ & $\begin{array}{l}59.9 \\
(50.2 \text { to } 71.0)\end{array}$ & $\begin{array}{l}68.5 \\
(58.2 \text { to } 80.0)\end{array}$ & $\begin{array}{l}92.3 \\
\text { (80.4 to } 105.4)\end{array}$ & 66.3 & $<0.0001$ \\
\hline $27-48$ & $\begin{array}{l}33.4 \\
\text { (26.3 to } 41.8)\end{array}$ & $\begin{array}{l}34.3 \\
(27.2 \text { to } 42.7)\end{array}$ & $\begin{array}{l}30.3 \\
(23.5 \text { to } 38.4)\end{array}$ & $\begin{array}{l}39.1 \\
\text { (31.3 to } 48.2 \text { ) }\end{array}$ & $\begin{array}{l}42.6 \\
(34.6 \text { to } 52.0)\end{array}$ & 36.0 & 0.0628 \\
\hline $49-60$ & $\begin{array}{l}20.7 \\
(15.0 \text { to } 27.7)\end{array}$ & $\begin{array}{l}21.0 \\
(15.5 \text { to } 27.9)\end{array}$ & $\begin{array}{l}13.7 \\
(9.4 \text { to } 19.4)\end{array}$ & $\begin{array}{l}15.3 \\
(10.6 \text { to } 21.4)\end{array}$ & $\begin{array}{l}18.9 \\
\text { (13.6 to } 25.5)\end{array}$ & 17.9 & 0.3030 \\
\hline $61-72$ & $\begin{array}{l}12.8 \\
(8.5 \text { to } 18.5)\end{array}$ & $\begin{array}{l}6.6 \\
(3.6 \text { to } 11.0)\end{array}$ & $\begin{array}{l}11.8 \\
\text { (7.8 to } 17.2)\end{array}$ & $\begin{array}{l}8.1 \\
(4.9 \text { to } 12.7)\end{array}$ & $\begin{array}{l}9.0 \\
(5.5 \text { to } 13.9)\end{array}$ & 9.7 & 0.3520 \\
\hline $73-84$ & $\begin{array}{l}3.0 \\
(1.2 \text { to } 6.2)\end{array}$ & $\begin{array}{l}4.6 \\
(2.2 \text { to } 8.4)\end{array}$ & $\begin{array}{l}3.8 \\
(1.6 \text { to } 7.4)\end{array}$ & $\begin{array}{l}5.3 \\
(2.7 \text { to } 9.2)\end{array}$ & $\begin{array}{l}3.8 \\
(1.8 \text { to } 7.3)\end{array}$ & 4.1 & 0.5720 \\
\hline $85-96$ & $\begin{array}{l}1.3 \\
(0.3 \text { to } 3.7)\end{array}$ & $\begin{array}{l}1.7 \\
(0.5 \text { to } 4.4)\end{array}$ & $\begin{array}{l}0.9 \\
(0.1 \text { to } 3.3)\end{array}$ & $\begin{array}{l}1.9 \\
(0.5 \text { to } 4.8)\end{array}$ & $\begin{array}{l}0.9 \\
(0.1 \text { to } 3.2)\end{array}$ & 1.3 & 0.7809 \\
\hline Total & $\begin{array}{l}36.1 \\
(33.4 \text { to } 39.0)\end{array}$ & $\begin{array}{l}45.6 \\
(42.5 \text { to } 48.8)\end{array}$ & $\begin{array}{l}45.5 \\
(42.4 \text { to } 48.7)\end{array}$ & $\begin{array}{l}65.1 \\
(61.5 \text { to } 69.0)\end{array}$ & $\begin{array}{l}82.7 \\
\text { (78.5 to } 87.0)\end{array}$ & 55.0 & $<0.0001$ \\
\hline
\end{tabular}

Annual incidence shown as number of persons per 100000 person-years with $95 \% \mathrm{Cl}$ in the parentheses.

explained by the role of vigilant inspection of the physician, enabling the inclusion of asymptomatic LA cases (figure 1). As the KDST registry was voluntary rather than mandatory and the referral to the paediatric gynaecologist was based on the primary physician's discretion, the data in this study fall short of representing the real number of LAs in South Korea. With all the shortcomings standing, the strength of this study still lies in the involvement of 4934 newly developed LA cases, which is quite large a number considering the rarity of LA.

In this study, the group of 13 to 24 months showed the highest average incidence of 183.6 cases $/ 100000$ personyears (95\% CI 175.8 to 191.6) (table 2, figure 2). McCann et al reported a much higher incidence where 35 out of 90 girls being examined (38.9\%) showed LA. The use of magnified colposcopy photographs as diagnostic tool might have included very small lesions that could have been easily missed with naked-eye observation. ${ }^{8}$

Some authors even argue that LA might be considered as an incidental normal finding in female infants because the small size of the external genitalia provides a natural opportunity for the labia to lie in apposition for most of the day resulting in temporal formation of LA. ${ }^{9}$ No longterm follow-up of untreated LA has ever been conducted, rendering the natural course of LA to be revealed.

In contrary to the possibility of spontaneous remission of LA, the importance of prudent physical examination and proper treatment of LA in referred patients of intractable recurrent urinary tract infection (UTI) has been emphasised by Melek et al. None of the primary physicians performed a gynaecological examination and only focused on urine culture, cystoscopy and

Table 2 Average incidence of labial adhesion per 100000 person-years classified by age group from 2010 to 2014

\begin{tabular}{|llllll|}
\hline $\begin{array}{l}\text { Age } \\
\text { (months) }\end{array}$ & Labial adhesion & Population & $\begin{array}{l}\text { Proportion in age } \\
\text { group (\%) }\end{array}$ & $\begin{array}{l}\text { Incident } \\
\text { cases/100 } 000 \\
\text { person-years }\end{array}$ & $\mathbf{9 5 \% ~} \mathbf{~}$ I \\
\hline $0-12$ & 1330 & 1072757 & 27 & 124.0 & 117.4 to 130.8 \\
\hline $13-24$ & 2072 & 1128683 & 42 & 183.6 & 175.8 to 191.6 \\
\hline $25-36$ & 755 & 1138727 & 15 & 66.3 & 61.7 to 71.2 \\
\hline $37-48$ & 408 & 1134383 & 8 & 36.0 & 32.6 to 39.6 \\
\hline $49-60$ & 200 & 1118929 & 4 & 17.9 & 15.5 to 20.5 \\
\hline $61-72$ & 108 & 1115703 & 2 & 9.7 & 7.9 to 11.7 \\
\hline $73-84$ & 46 & 1126805 & 1 & 4.1 & 3.0 to 5.4 \\
\hline $85-96$ & 15 & 1129854 & 0 & 1.3 & 0.7 to 2.2 \\
\hline Total & 4934 & 8965839 & 100 & 55.0 & 53.5 to 56.6 \\
\hline
\end{tabular}




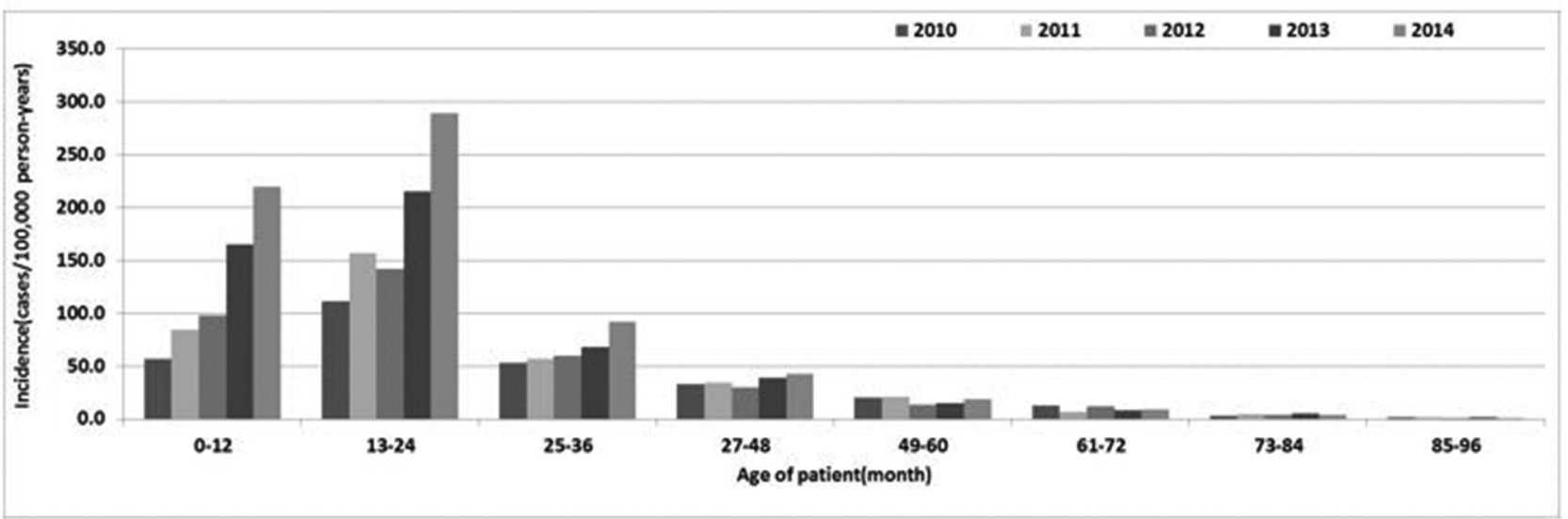

Figure 2 Annual cases of labial adhesions per 100000 person-years from 2010 to 2014 by age groups.

ultrasonography. For the avoidance of unnecessary invasive procedures, the importance of physical examination to rule out LA was emphasised. ${ }^{10}$

The relative risk of acquiring LA in the age group of 13 to 24 months was 1.481 (95\% CI 1.381 to 1.587 ) compared with the reference age group of 0 to 12 months (table 3 ). This is the age bracket where diaper usage might cause constant irritation resulting in LA. Explaining the natural progression of LA that often results in spontaneous resolution and emphasising that this is not a congenital disease should calm the overly concerned parents with respect to the appearance of their child's external genitalia occurring in the absence of overt symptoms. Fondling, masturbation, trauma or sexual abuse are some other external irritation factors causing LA. ${ }^{11}$

Management algorithms for LA start with the recognition of associated symptoms such as rash, recurrent UTI, dribbling of the urine due to outlet obstruction, and dysuria. ${ }^{5}$ If asymptomatic, follow-up without intervention may suffice because the primary goal of treating LA should be no other than the resolution of the clinical symptoms associated with it. If symptomatic, either oestrogen vaginal cream application or surgical separation might be options. ${ }^{12} 13$ As most of the studies published so far only included a small study population in a single institute, a larger study with the cooperation

Table 3 Relative risk of acquiring labial adhesion classified by age group from 2010 to 2014

\begin{tabular}{llll|}
\hline Age (months) & Relative risk & $\mathbf{9 5 \%} \mathbf{~ C l}$ & P values \\
\hline $0-12$ & 1 & - & \\
\hline $13-24$ & 1.481 & 1.381 to 1.587 & $<0.0001$ \\
\hline $25-36$ & 0.535 & 0.488 to 0.585 & $<0.0001$ \\
\hline $37-48$ & 0.290 & 0.259 to 0.324 & $<0.0001$ \\
\hline $49-60$ & 0.144 & 0.124 to 0.167 & $<0.0001$ \\
\hline $61-72$ & 0.078 & 0.064 to 0.095 & $<0.0001$ \\
\hline $73-84$ & 0.033 & 0.024 to 0.044 & $<0.0001$ \\
\hline $85-96$ & 0.011 & 0.006 to 0.018 & $<0.0001$ \\
\hline
\end{tabular}

of multiple institutes is warranted to set up the ideal treatment algorithm and methodology.

Based on the population-based national registry, a total of 4934 newly developed LA cases in South Korea were analysed. The average incidence of LA was 55.0 cases/100 000 person-years from 2010 to 2014. The age group of 13 to 24 months showed the highest average incidence of 183.6 cases $/ 100000$ person-years (95\% CI 175.8 to 191.6), coinciding with the hypo-oestrogenic milieu and persistent irritation due to diaper usage. Proper hygiene as a means of treatment should be emphasised before considering unnecessary intervention and the chance of spontaneous resolution with proper lifestyle adjustment should be kept in mind. Further studies are needed to reveal the natural disease course and the significance of diagnosing asymptomatic LA cases.

Contributors JEC and IOL contributed equally in the analysis of the data, manuscript preparation and revision. HYP provided the statistical support.

Funding This work was supported by a National Health Insurance Ilsan Hospital grant (NHIMC 2015-07-013-001).

Competing interests None declared.

Patient consent Not required.

Ethics approval The KNICD was accessed with the approval from the Institutional Review Board of the National Health Insurance Service Ilsan Hospital, South Korea (NHIS-2016-1-171).

Provenance and peer review Not commissioned; externally peer reviewed.

Data sharing statement All data concerning this study are included in this published article.

Open access This is an open access article distributed in accordance with the Creative Commons Attribution Non Commercial (CC BY-NC 4.0) license, which permits others to distribute, remix, adapt, build upon this work non-commercially, and license their derivative works on different terms, provided the original work is properly cited and the use is non-commercial. See: http://creativecommons.org/ licenses/by-nc/4.0/

(C) Article author(s) (or their employer(s) unless otherwise stated in the text of the article) 2018. All rights reserved. No commercial use is permitted unless otherwise expressly granted.

\section{REFERENCES}

1. Gibbon KL, Bewley AP, Salisbury JA. Labial fusion in children: a presenting feature of genital lichen sclerosus? Pediatr Dermatol 1999;16:388-91. 
2. Starr NB. LAs in childhood. J Pediatr Health Care 1996;10:26-7.

3. Granada C, Sokkary N, Sangi-Haghpeykar H, et al. Labial adhesions and outcomes of office management. J Pediatr Adolesc Gynecol 2015;28:109-13.

4. Eroğlu E, Yip M, Oktar T, et al. How should we treat prepubertal labial adhesions? Retrospective comparison of topical treatments: estrogen only, betamethasone only, and combination estrogen and betamethasone. J Pediatr Adolesc Gynecol 2011;24:389-91.

5. Myers JB, Sorensen CM, Wisner BP, et al. Betamethasone cream for the treatment of pre-pubertal labial adhesions. J Pediatr Adolesc Gynecol 2006;19:407-11.

6. Muram D. Treatment of prepubertal girls with labial adhesions. $J$ Pediatr Adolesc Gynecol 1999;12:67-70.

7. Leung AK, Robson WL, Kao CP, et al. Treatment of labial fusion with topical estrogen therapy. Clin Pediatr 2005;44:245-7.
8. McCann J, Wells R, Simon M, et al. Genital findings in prepubertal girls selected for nonabuse: a descriptive study. Pediatrics 1990;86:428-39.

9. Berenson $A B$, Heger $A H$, Hayes JM, et al. Appearance of the hymen in prepubertal girls. Pediatrics 1992;89:387-94.

10. Melek E, Kilıçbay F, Sarıkaș NG, et al. Labial adhesion and urinary tract problems: the importance of genital examination. J Pediatr Uro 2016;12:111.e1-111.e5.

11. Pokorny SF. Prepubertal vulvovaginopathies. Obstet Gynecol Clin North Am 1992;19:39-58.

12. Bacon JL, Romano ME, Quint EH, et al. Clinical recommendation: LAs. J Pediatr Adolesc Gynecol 2015;28:405-9.

13. Soyer T. Topical estrogen therapy in labial adhesions in children: therapeutic or prophylactic? J Pediatr Adolesc Gynecol 2007;20:241-4 